\title{
Diagnostic utility of the neutrophil-lymphocyte ratio in patients with acute mesenteric ischemia: A retrospective cohort study
}

\author{
Yusuf Tanrıkulu, M.D., ${ }^{1}$ Ceren Şen Tanrıkulu, M.D., ${ }^{2}$ Mehmet Zafer Sabuncuoğlu, M.D., ${ }^{3}$ \\ Ayetullah Temiz, M.D., ${ }^{4}$ Furuzan Köktürk, M.D., ${ }^{5}$ Boran Yalçın, M.D. ${ }^{1}$
}

\begin{abstract}
${ }^{1}$ Department of General Surgery, Zonguldak Atatürk State Hospital, Zonguldak-Turkey
${ }^{2}$ Department of Emergency Medicine, Bülent Ecevit University Faculty of Medicine, Zonguldak-Turkey

${ }^{3}$ Department of General Surgery, Süleyman Demirel University Faculty of Medicine, Isparta-Turkey

${ }^{4}$ Department of General Surgery, Erzurum Area Training and Research Hospital, Erzurum-Turkey

${ }^{5}$ Department of Biostatistics, Bülent Ecevit University Faculty of Medicine, Zonguldak-Turkey
\end{abstract}

\begin{abstract}
BACKGROUND: Acute mesenteric ischemia (AMI) remains fatal in 50-70\% of cases. AMI is recognized as a vascular emergency, requiring rapid and efficient clinical evaluation and treatment. In the present retrospective study, the possible utility of the neutrophillymphocyte ratio (NLR) in the early diagnosis of AMI was explored. The potential use of this ratio to distinguish AMI from non-vascular bowel necrosis (NVBN) was investigated.
\end{abstract}

METHODS: A total of 58 AMI, 62 NVBN, and 62 control patients were enrolled between May I, 20I0 and April 30, 20I5. Patients who underwent laparotomies and/or bowel resections to treat AMI were included, as were NVBN patients who underwent segmental bowel resection to treat incarcerated and strangulated hernias. Controls were patients who presented to the emergency room with non-specific abdominal pain.

RESULTS: Mortality rate was $51.7 \%$ in the AMI and $4.8 \%$ in the NVBN groups. White blood cell (WBC) count, C-reactive protein (CRP) level, and red cell distribution width (RDW) were highest in the AMI group. NLR was higher in the AMI and NVBN groups than in the control group $(p<0.00 \mathrm{I})$, though no difference in NLR was found between the AMI and NVBN groups. In addition, WBC count, CRP level, and NLR were higher in the NVBN group than in the controls $(p<0.00 \mathrm{I})$.

CONCLUSION: We suggest that preoperative NLR aids in the diagnosis of AMI, and can be used to distinguish this condition from NVBN. NLR should be calculated, in addition to clinical examination.

Keywords: Acute mesenteric ischemia; diagnosis; NLR; serum markers.

\section{INTRODUCTION}

Acute mesenteric ischemia (AMI), an abdominal emergency, is observed in I of every 1000 patients presenting to emergency rooms. Mortality from AMI remains high (40-70\%),

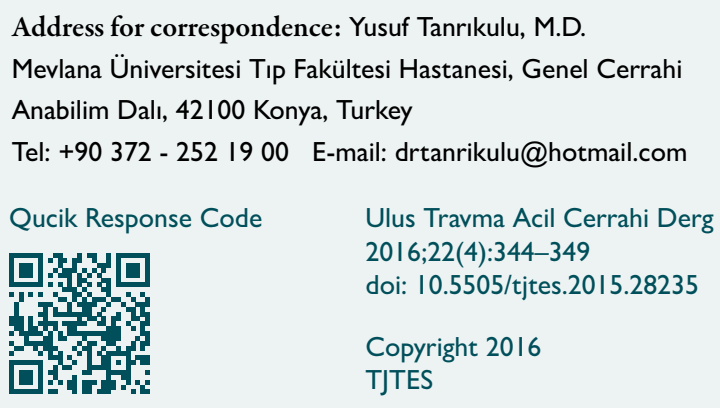

although diagnostic methods have advanced in recent years. An important contributor to mortality is the failure of timely diagnosis, as duration of ischemia affects $A M I$ outcome. ${ }^{[1,2]} A$ 24 -hour delay reduces survival rate by $20 \%$; early diagnosis is critical. ${ }^{[3]}$ However, early AMI signs and symptoms on physical examination are vague, laboratory data are non-specific, and imaging methods including duplex ultrasonography and computerized tomographic angiography are not sufficiently sensitive when used to explore distal vascular pathologies. ${ }^{[4,5]}$ Therefore, the development of new diagnostic methods is essential. An ideal biochemical marker should be highly specific and sensitive, measurable in a non-invasive manner, released from the intestinal mucosa, and should preferably be detectable in peripheral blood.

AMI is an acute inflammatory process; absorption of bacte- 
rial materials (including endotoxin) triggers inflammation that increases in extent as ischemia is prolonged, causing bacterial infiltration, sepsis, acidosis, septic shock, and, ultimately, death. During this process, inflammatory substances measurable in peripheral blood are released from necrotic cells of the gut wall. ${ }^{[2,6]}$ Recent studies have focused on such materials because early and accurate detection of inflammation is essential in order to optimize treatment and prognosis of those with medical emergencies. ${ }^{[7]}$ Several biomarkers, such as $\mathrm{C}$-reactive protein (CRP), procalcitonin, and mean platelet volume (MPV) have been used as indicators of inflammation. Neutrophilia develops during inflammation, triggered by release of arachidonic acid metabolites and platelet activation. Such stress induces relative lymphopenia. Therefore, the neutrophil-lymphocyte ratio (NLR) accurately reflects underlying inflammatory processes. ${ }^{[8]}$ Although several studies have explored the utility of NLR in the diagnosis and prognosis of inflammatory and malignant diseases, very rarely has NLR been used in the diagnosis of AMI.. ${ }^{[9-1]}$ In the present study, the diagnostic capacity of NLR was evaluated and compared to traditional parameters in such patients.

\section{MATERIALS AND METHODS}

\section{Study Groups and Study Design}

The present retrospective, cross-sectional, multi-center study was approved by the local ethics committee. A total of $58 \mathrm{AMI}$ patients, 62 non-vascular bowel necrosis (NVBN) patients, and 62 control patients were enrolled. Each patient was treated in I of 3 hospitals: the Zonguldak Atatürk State Hospital, a 450-bed, 12-section, government-approved general hospital with high direct admission and referral rates, the Süleyman Demirel University Faculty of Medicine Hospital, a 400-bed, 14-section, government-approved general hospital with a high direct admission rate, or the Erzurum Regional Training and Research Hospital, a 700-bed, 18-section, government-approved general hospital with high direct admission and referral rates. Patients were enrolled between May I, 2010 and April 30, 20I5. Archived and electronically stored records were accessed.

Patients who underwent laparotomies and/or bowel resections to treat AMI were included, as were NVBN patients who underwent segmental bowel excision to treat incarcerated and strangulated hernias. The control group included patients who presented to the emergency department with non-specific abdominal pain. Pre-study power analysis showed that the chosen sample size afforded a power of 0.9 for achievement of $95 \%$ confidence interval.

\section{Complete Blood Count and Biochemical Analysis}

Biochemical tests and complete blood count (CBC) (on venous blood) were automated. CBC data from all 3 hospitals were similar to recognized international norms. White blood cell (WBC) count, MPV, and red cell distribution width
(RDW) were evaluated, and NLRs were calculated. Normal values of all parameters were reference figures accepted by hematology laboratories nationwide.

\section{Statistical Analysis}

Statistical analyses were performed using SPSS software (version 19.0; SPSS Inc., Chicago, IL, USA). Data distribution was evaluated using the Kolmogorov-Smirnov test. Continuous variables were expressed as mean $\pm S D$ and categorical variables as frequencies (percentages). Significance of each difference among continuous variables was explored using independent samples t-test or Mann-Whitney $U$ test. Significance of each difference between categorical variables was compared using Pearson chi-squared test. Receiver operating characteristic (ROC) curve analysis was used to define optimal cut-offs of NLR and RDW, for which specificities, sensitivities, positive and negative predictive values (PPV, NPV), and overall accuracies were calculated. Youden index was used to optimize accuracies of all calculations. A p value of less than 0.05 was considered to reflect statistical significance.

\section{RESULTS}

A total of $58 \mathrm{AMI}, 62 \mathrm{NVBN}$, and 62 control patients were enrolled. Mean patient age did not differ significantly among groups, being $68.43,66.43$, and 63.38 years, respectively. Of the AMI patients, 31 (36.2\%) were female and 37 (63.8\%) male, 26 (4I.9\%) NVBN patients were female and 36 (58.1\%) male, and $28(45.2 \%)$ control patients were female and 34 (54.8\%) male. Patient profiles differed somewhat among the 3 hospitals, reflecting local population densities and hospital capacities.

Regarding affected bowels, segmental involvement was evident in $39(67.2 \%)$ AMI patients, with complete involvement in $19(32.8 \%)$. Forty-two (72.4\%) patients exhibited only small bowel involvement, but $16(27.6 \%)$ exhibited both small intestinal and colonic involvement. Segmental involvement was evident in all NVBN patients. Mortality rates were $51.7 \%$ in the AMl group and $4.8 \%$ in the NVBN group.

WBC counts, CRP levels, RDWs, MPVs, and NLRs are shown in Figures I-4, as well as in Table I. WBC counts and CRP levels were significantly higher in the AMI group than in the other groups ( $p=0.028$ vs the NVBN group; $p<0.001$ vs controls in terms of WBC count; $p<0.00$ I vs the NVBN and control groups in terms of CRP). RDW was significantly higher in the AMI group ( $p=0.002)$. MPV did not differ among groups $(p=0.18 I)$. NLR was significantly higher in the AMI group than in the control group $(p<0.001)$. WBC, CRP level, and NLR (but not RDW, $p=1.000$ ) were significantly higher in the NVBN group than in the controls $(p<0.001$ for all).

Sensitivities and specificities of CRP levels and CBC data used to distinguish controls from AMI patients, and ROC 


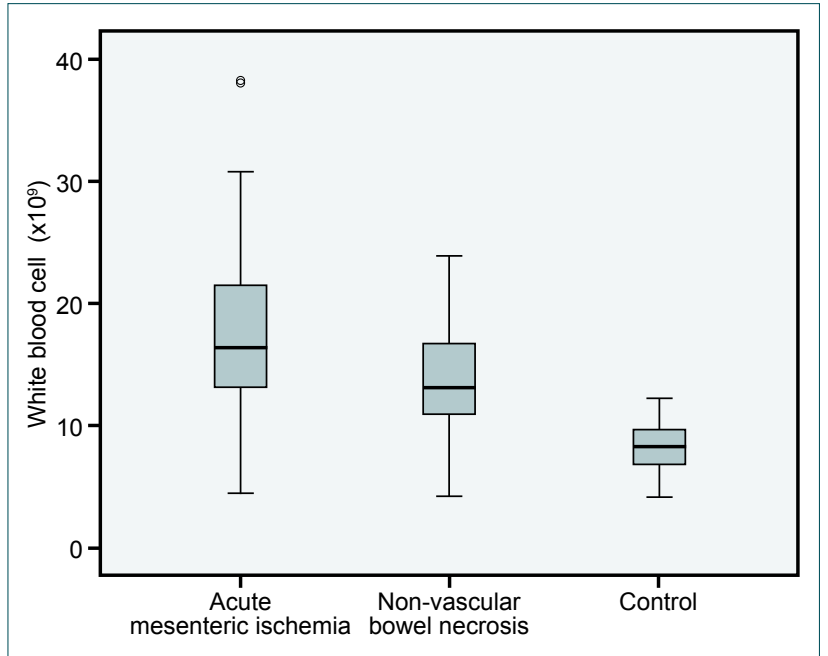

Figure 1. Distribution among groups of WBC counts.

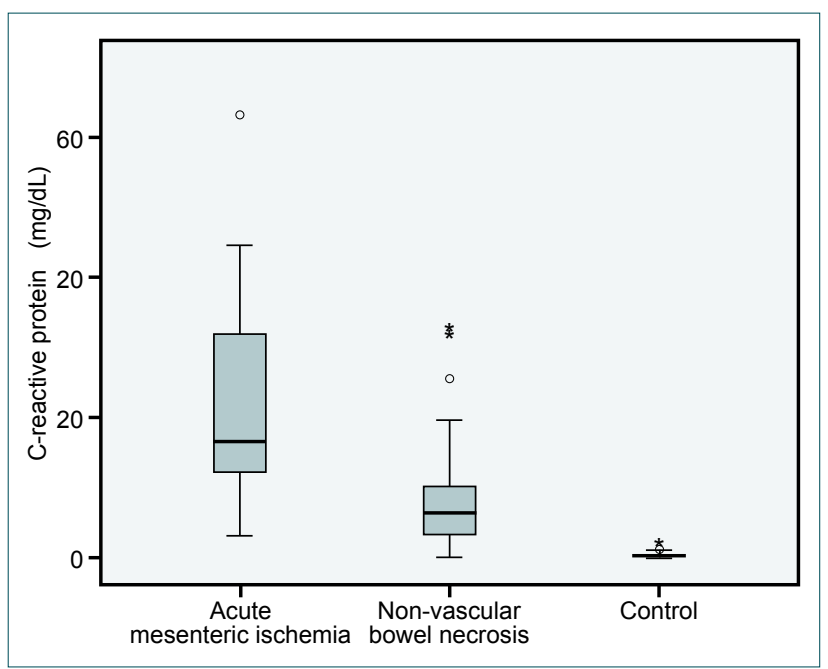

Figure 2. Distribution among groups of CRP levels.

curve analysis data on WBC counts, RDWs, and NLRs are shown in Table 2 and Figure 5. Sensitivities, specificities, PPVs, and NPVs of WBC counts (>10×10\%/L) and CRP levels $(>0.5 \mathrm{mg} / \mathrm{dL})$ were $86.21 \%, 95.16 \%, 94.30 \%$, and $88.10 \%$, and $100 \%, 100 \%, 100 \%$, and $100 \%$, respectively. Sensitivities, specificities, PPVs, and NPVs of NLRs were 74.14\%, 88.7I\%, $86 \%$, and $78.60 \%$. The same figures for RDWs were $48.28 \%$,

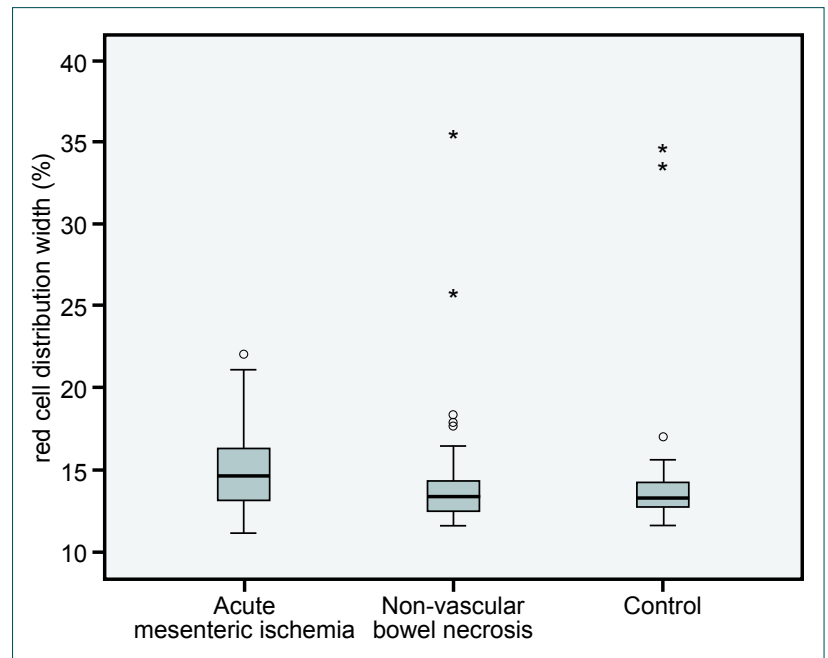

Figure 3. Distribution among groups of RDWs.

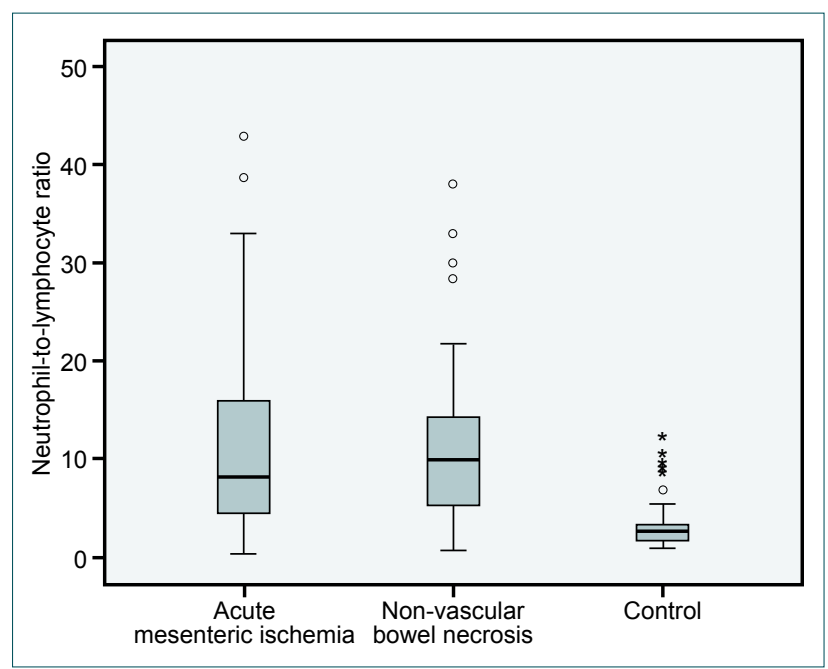

Figure 4. Distribution among groups of NLR ratios.

$88.71 \%, 80 \%$, and $64.70 \%$, respectively. Youden index values for WBC count, CRP, RDW, and NLR were 0.814, I.000, 0.369, and 0.628, respectively. ROC analysis showed that WBC count, CRP level, RDW, and NLR cut-off values that afforded optimal sensitivities and specificities were $10.99 \times 10 \% / \mathrm{L}$ (86-95\%), $2.10 \mathrm{mg} / \mathrm{dL}$ (100-100\%), $14.70 \%$ (48-89\%), and 5.2I (74-89\%), respectively. Areas under the

Table I. Laboratory data from all groups

\begin{tabular}{|c|c|c|c|}
\hline & $\begin{array}{l}\text { Acute mesenteric ischemia } \\
\qquad(\mathrm{n}=58)\end{array}$ & $\begin{array}{l}\text { Non-vascular bowel necrosis } \\
(n=62)\end{array}$ & $\begin{array}{l}\text { Control } \\
(n=62)\end{array}$ \\
\hline White blood cell (x109/L) & $16.38(4.48-38.20)^{\# . *}$ & $13.10(4.20-23.90)^{*}$ & $8.28(4.15-12.23)$ \\
\hline C-reactive protein $(\mathrm{mg} / \mathrm{dL})$ & $16.60(3.20-63.20)^{*, t}$ & $6.40(0.10-33.00)^{*}$ & $0.20(0-2.10)$ \\
\hline Red cell distribution width (\%) & $14.55(11.10-22.10)^{*}$ & $13.35(11.60-35.40)$ & $13.30(11.60-34.60)$ \\
\hline Mean platelet volume $(\mathrm{fL})$ & $8.67 \pm 1.47$ & $8.50 \pm 1.37$ & $8.93 \pm 1.03$ \\
\hline Neutrophil-to-lymphocyte ratio & $8.16(0.36-42.87)^{*}$ & $9.92(0.75-38.00)^{*}$ & $2.68(0.96-12.28)$ \\
\hline
\end{tabular}

${ }^{\#} p=0.028$ vs. non-vascular bowel necrosis, ${ }^{*} p<0.001$ vs. control, ${ }^{t} p<0.001$ vs. non-vascular bowel necrosis, ${ }^{*} p=0.002$ vs. non-vascular bowel necrosis and control. 
Table 2. Overall accuracies afforded by laboratory parameters used to distinguish AMI patients from controls (\%)

\begin{tabular}{lcccccc}
\hline & Sensitivity & Specificity & PPD & NPD & Cut-off & Youden's Index \\
\hline White blood cell & 86.21 & 95.16 & 94.30 & 88.10 & 10.99 & 0.814 \\
C-reactive protein & 100 & 100 & 100 & 100 & 2.10 & 1.000 \\
Red cell distribution width & 48.28 & 88.71 & 80 & 64.70 & 14.70 & 0.369 \\
Mean platelet volume & 46.55 & 70.97 & 60 & 58.70 & 8.30 & 0.175 \\
Neutrophil-to-lymphocyte ratio & 74.14 & 88.71 & 86 & 78.60 & 5.21 & 0.628 \\
\hline
\end{tabular}

NPV: Negative predictive value; PPD: Positive predictive value.

Table 3. Overall accuracies afforded by laboratory parameters used to distinguish AMI patients from NVBN patients (\%)

\begin{tabular}{lcccccc}
\hline & Sensitivity & Specificity & PPD & NPD & Cut-off & Youden's Index \\
\hline White blood cell & 67.24 & 66.13 & 65 & 68.30 & 14.50 & 0.334 \\
C-reactive protein & 89.66 & 72.58 & 75.40 & 88.20 & 8.50 & 0.622 \\
Red cell distribution width & 65.52 & 66.13 & 64.40 & 67.20 & 13.90 & 0.317 \\
Mean platelet volume & 81.03 & 24.72 & 51.10 & 60.70 & 7.40 & 0.057 \\
Neutrophil-to-lymphocyte ratio & 50.00 & 66.13 & 58 & 58.60 & 7.85 & 0.161 \\
\hline
\end{tabular}

NPV: Negative predictive value; PPD: Positive predictive value.

curves (AUCs) for WBC count, RDW, and NLR were $93.4 \%$, $69.7 \%$, and $81.9 \%$, respectively.

Sensitivities and specificities of CRP levels and $C B C$ data used to distinguish NVBN and AMI patients, and ROC data on WBC counts, RDWs, and NLRs, are shown in Table 3 and Figure 6. Sensitivities, specificities, PPVs, and NPVs of WBC counts $\left(>10 \times 10^{9} / \mathrm{L}\right)$ and CRP levels $(>0.5 \mathrm{mg} / \mathrm{dL})$ were $67.24 \%$, $66.13 \%, 65 \%$, and $68.30 \%$, and $89.66 \%, 72.58 \%, 75.40 \%$, and

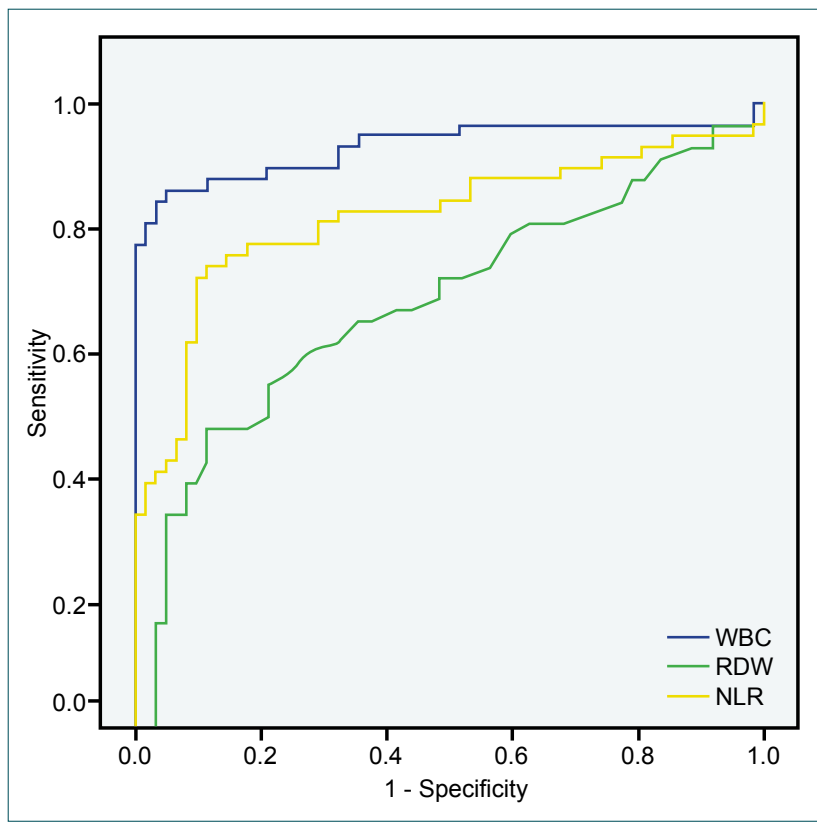

Figure 5. ROC curve used to distinguish AMI patients from controls.
$88.20 \%$, respectively. Sensitivities, specificities, PPVs, and NPVs of NLRs were $50 \%, 66.13 \%, 58 \%$, and $58.60 \%$, respectively. Those of RDWs were $65.52 \%, 66.13 \%, 64.40 \%$, and $67.20 \%$, respectively. Youden index values for WBC count, CRP level, RDW, and NLR were 0.334, 0.622, 0.317, and 0.161 , respectively. ROC analysis showed that WBC count, CRP level, RDW, and NLR cut-off values affording the best sensitivities and specificities were $14.50 \times 10^{\circ} / \mathrm{L}(67-66 \%), 8.50$ $\mathrm{mg} / \mathrm{dL}(90-73 \%)$, $13.90 \%$ (66-66\%), and 7.85\% (50-66\%),

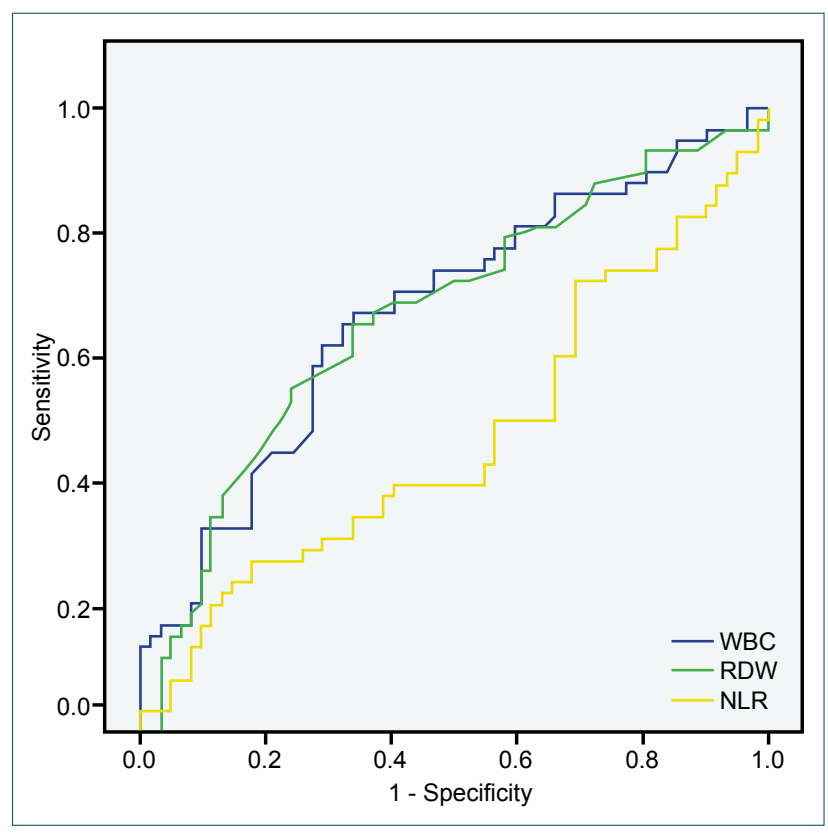

Figure 6. ROC curve used to distinguish AMI from NVBN patients. 
respectively. AUCs for WBC count, RDW, and NLR were $67.4 \%, 67 \%$, and $47.4 \%$, respectively.

\section{DISCUSSION}

It was presently determined that NLR was highly sensitive and specific when used to identify patients with AMI (an abdominal emergency with a high mortality rate). Differential diagnosis of AMI must be urgently performed. Mean age of AMI patients exceeds 65 years. ${ }^{[12]}$ Kougias et al. ${ }^{[13]}$ reported a mean age of $7 \mathrm{I}$ years; the mean age of our AMI group was 68.43 years.

Early diagnosis and treatment of AMI are essential in the prevention of irreversible damage to the bowel wall. ${ }^{[14,15]}$ Any diagnosis that begins with a suspicion raised by clinical findings should be confirmed by laboratory and imaging methods. Clinical presentation of AMI is highly varied. Classically, the condition is associated with dramatic-onset severe abdominal pain, disproportionate to findings on physical examination. However, early correct diagnosis is often difficult, as many AMI signs and symptoms are shared by other emergency intra-abdominal pathologies, including appendicitis, pancreatitis, small intestine obstruction, and acute diverticulitis. ${ }^{[1,16]}$ Such problems have encouraged researchers to devise new laboratory and imaging methods. As AMl is an inflammatory process, intense effort has been devoted to the definition of specific early biochemical and serological markers of such inflammation. ${ }^{[17]}$ However, useful markers are few.

Classically, AMI patients exhibit leukocytosis, metabolic acidosis, and elevated levels of serum D-dimer and lactate. ${ }^{[18]}$ Although the leukocytosis is significant, it has been reported as unhelpful in differential diagnosis. ${ }^{[1]}$ However, in the retrospective study of Paladino et al., ${ }^{[19]}$ leukocytosis was a significant diagnostic and prognostic factor. In the present study, profound leukocytosis was evident in AMI patients $(p<0.00 \mathrm{I})$. Other useful parameters are D-dimer and serum lactate levels. ${ }^{[I]}$ These levels were not measured in the present patients.

NLR is a simple biomarker of inflammation. Total leukocyte and neutrophil counts have traditionally been considered markers of infection. Associations are evident between monocyte and lymphocyte counts, as well as between these counts and infection..$^{[7,20]}$ During inflammation, neutrophil counts increase as lymphocyte counts decrease, controlled by neurohormonal mechanisms. Therefore, NLR accurately reflects underlying inflammatory processes. ${ }^{[8]}$

NLR is increasingly used to predict the survival of patients with malignancies, coronary artery disease, acute appendicitis, acute cholecystitis, acute pancreatitis, and community-acquired infections. ${ }^{[7]}$ Lee et al. ${ }^{[2]}$ found that preoperative NLR accurately predicted the development of severe cholecystitis. Yu et al. ${ }^{[22]}$ found that preoperative NLR was prognostic for gastric cancer patients. Suppiah et al. ${ }^{[23]}$ found that NLR elevation during the first 48 hours of admission was significantly associated with severe acute pancreatitis, and was an independent (negative) prognostic factor. Kahramanca et al. ${ }^{[2]}$ found preoperative NLR useful in the diagnosis of acute appendicitis, as well as in the differentiation of patients with simple and complicated appendicitis. Aktimur et al. ${ }^{[1]}$ found high NLR (<9.99) valuable in AMI diagnosis. In addition, RDW was higher in AMI patients than in those with acute appendicitis, and MPV was higher in AMI patients than in controls. In the present study, NLRs were higher in the AMI and NVBN groups than in the control group $(p<0.001)$. However, no difference was found between the AMI and NVBN groups in this respect $(p=1.000)$. Unlike the findings of Aktimur et al., ${ }^{[1]}$ the present MPVs were similar in all groups $(p=0.181)$. RDWs were higher in the AMI group than in the other groups $(p=0.002)$, but did not differ between the NVBN and control groups $(p=1.000)$.

In terms of AMI diagnosis, sensitivity of $80 \%$ and specificity of $50 \%$ was afforded by WBC count; the same figures for the NLR were $69 \%$ and $71 \% .^{[2,11]}$ In an earlier study ${ }^{[25]}$ of RDW in the context of diagnosing AMI, cut-off value, sensitivity, and specificity were $15.04 \%, 40.8 \%$, and $81.2 \%$, respectively. Another study ${ }^{[26]}$ found that the AUC for RDW was 0.7I3, and that the cut-off value was $14.85 \%$. Sensitivities, specificities, PPVs, and NPVs for WBC count, RDW, and NLR were $86.21 \%$, 95.14\%, 94.30\%, and 88.10\%; 48.28\%, $88.71 \%$, $80 \%$, and $64.70 \%$; and $74.14 \%, 88.71 \%, 86 \%$, and $78.60 \%$, respectively. RDW and NLR data were consistent with published findings, but WBC count figures were higher. ROC analysis yielded cut-offs for WBC count, RDW, and NLR, as well as for optimal sensitivities and specificities. These were $14.50 \times 10^{9} / \mathrm{L}$ (67-66\%), 13.90\% (66-66\%), and 7.85 (50-66\%), respectively.

In conclusion, preoperative NLR aids in the diagnosis of AMI, differentiating the condition from NVBN, and can be used as an adjunct to clinical examination.

\section{Conflict of interest: None declared.}

\section{REFERENCES}

1. van den Heijkant TC, Aerts BA, Teijink JA, Buurman WA, Luyer MD. Challenges in diagnosing mesenteric ischemia. World J Gastroenterol 2013;19:1338-41. Crossref

2. Evennett NJ, Petrov MS, Mittal A, Windsor JA. Systematic review and pooled estimates for the diagnostic accuracy of serological markers for intestinal ischemia. World J Surg 2009;33:1374-83. Crossref

3. Karabulut K, Gül M, Dündar ZD, Cander B, Kurban S, Toy H. Diagnostic and prognostic value of procalcitonin and phosphorus in acute mesenteric ischemia. Ulus Travma Acil Cerrahi Derg 2011;17:193-8.

4. Hamzaoğlu I, Ulualp K, Balkan T, Şirin F. Abdominal emergencies in octogenerians. Ulus Travma Acil Cerrahi Derg 2000;6:36-8.

5. Demir IE, Ceyhan GO, Friess H. Beyond lactate: is there a role for serum lactate measurement in diagnosing acute mesenteric ischemia?. Dig Surg 2012;29:226-35. Crossref

6. Klar E, Rahmanian PB, Bücker A, Hauenstein K, Jauch KW, Luther B. Acute mesenteric ischemia: a vascular emergency. Dtsch Arztebl Int 2012;109:249-56. 
7. de Jager CP, van Wijk PT, Mathoera RB, de Jongh-Leuvenink J, van der Poll T, Wever PC. Lymphocytopenia and neutrophil-lymphocyte count ratio predict bacteremia better than conventional infection markers in an emergency care unit. Crit Care 2010;14:R192. Crossref

8. Tamhane UU, Aneja S, Montgomery D, Rogers EK, Eagle KA, Gurm HS. Association between admission neutrophil to lymphocyte ratio and outcomes in patients with acute coronary syndrome. Am J Cardiol 2008;102:653-7. Crossref

9. Ishizuka M, Shimizu T, Kubota K. Neutrophil-to-lymphocyte ratio has a close association with gangrenous appendicitis in patients undergoing appendectomy. Int Surg 2012;97:299-304. Crossref

10. Azab B, Jaglall N, Atallah JP, Lamet A, Raja-Surya V, Farah B, et al. Neutrophil-lymphocyte ratio as a predictor of adverse outcomes of acute pancreatitis. Pancreatology 2011;11:445-52. Crossref

11. Aktimur R, Cetinkunar S, Yildirim K, Aktimur SH, Ugurlucan M, Ozlem N. Neutrophil-to-lymphocyte ratio as a diagnostic biomarker for the diagnosis of acute mesenteric ischemia. Eur J Trauma Emerg Surg 2015.

12. Gün B, Yolcu S, Değerli V, Elçin G, Tomruk Ö, Erdur B, et al. Multidetector angio-CT and the use of D-dimer for the diagnosis of acute mesenteric ischemia in geriatric patients. Ulus Travma Acil Cerrahi Derg 2014;20:376-81. Crossref

13. Kougias P, Lau D, El Sayed HF, Zhou W, Huynh TT, Lin PH. Determinants of mortality and treatment outcome following surgical interventions for acute mesenteric ischemia. J Vasc Surg 2007;46:467-74. Crossref

14. Öz B, Akyüz M, Emek E, Sözüer E, Akylldız H, Akcan A, et al. The effectiveness of gastric tonometry in the diagnosis of acute mesenteric ischemia in cases where a contrast-enhanced computed tomography cannot be obtained. Ulus Cerrahi Derg 2014;31:26-9.

15. Bradbury AW, Brittenden J, McBride K, Ruckley CV. Mesenteric ischaemia: a multidisciplinary approach. Br J Surg 1995;82:1446-59. Crossref

16. Wyers MC. Acute mesenteric ischemia: diagnostic approach and surgical treatment. Semin Vasc Surg 2010;23:9-20. Crossref
17. Gönüllü D, Yankol Y, Işiman F, Akyildiz Iğdem A, Yücel O, Köksoy FN. $\mathrm{pH}$ value and potassium level of diagnostic peritoneal lavage fluid in the early diagnosis of acute mesenteric ischemia secondary to arterial occlusion in rats. [Article in Turkish] Ulus Travma Acil Cerrahi Derg 2007;13:261-7.

18. Oldenburg WA, Lau LL, Rodenberg TJ, Edmonds HJ, Burger CD. Acute mesenteric ischemia: a clinical review. Arch Intern Med 2004;164:105462. Crossref

19. Paladino NC, Inviati A, Di Paola V, Busuito G, Amodio E, Bonventre $\mathrm{S}$, et al. Predictive factors of mortality in patients with acute mesenteric ischemia. A retrospective study. Ann Ital Chir 2014;85:265-70.

20. Wyllie DH, Bowler IC, Peto TE. Relation between lymphopenia and bacteraemia in UK adults with medical emergencies. J Clin Pathol 2004;57:950-5. Crossref

21. Lee SK, Lee SC, Park JW, Kim SJ. The utility of the preoperative neutrophil-to-lymphocyte ratio in predicting severe cholecystitis: a retrospective cohort study. BMC Surg 2014;14:100. Crossref

22. Yu L, Lv CY, Yuan AH, Chen W, Wu AW. Significance of the preoperative neutrophil-to-lymphocyte ratio in the prognosis of patients with gastric cancer. World J Gastroenterol 2015;21:6280-6. Crossref

23. Suppiah A, Malde D, Arab T, Hamed M, Allgar V, Smith AM, et al. The prognostic value of the neutrophil-lymphocyte ratio (NLR) in acute pancreatitis: identification of an optimal NLR. J Gastrointest Surg 2013;17:675-81. Crossref

24. Kahramanca S, Ozgehan G, Seker D, Gökce EI, Seker G, Tunç G, et al. Neutrophil-to-lymphocyte ratio as a predictor of acute appendicitis. Ulus Travma Acil Cerrahi Derg 2014;20:19-22. Crossref

25. Kisaoglu A, Bayramoglu A, Ozogul B, Atac K, Emet M, Atamanalp SS. Sensitivity and specificity of red cell distribution width in diagnosing acute mesenteric ischemia in patients with abdominal pain. World J Surg 2014;38:2770-6. Crossref

26. Bilgiç I, Dolu F, Şenol K, Tez M. Prognostic significance of red cell distribution width in acute mesenteric ischemia. Perfusion 2015;30:161-5.

\title{
ORİIINAL ÇALIŞMA - ÖZET
}

\section{Akut mezenterik iskemili hastalarda nötrofil-lenfosit oranının tanısal yararı: Geriye dönük kohort çalışma \\ Dr. Yusuf Tanrıkulu, ${ }^{1}$ Dr. Ceren Şen Tanrıkulu, ${ }^{2}$ Dr. Mehmet Zafer Sabuncuoğlu, ${ }^{3}$ Dr. Ayetullah Temiz, ${ }^{4}$ Dr. Furuzan Köktürk, ${ }^{5}$ Dr. Boran Yalçın ${ }^{1}$}

\begin{abstract}
'Zonguldak Atatürk Devlet Hastanesi, Genel Cerrahi Kliniği, Zonguldak
²Bülent Ecevit Üniversitesi Tıp Fakültesi, Acil Tıp Anabilim Dalı, Zonguldak

${ }^{3}$ Süleyman Demirel Üniversitesi Tıp Fakültesi, Genel Cerrahi Anabilim Dalı, Isparta

${ }^{4}$ Erzurum Bölge Eğitim ve Araştırma Hastanesi, Genel Cerrahi Kliniği, Erzurum

${ }^{5}$ Bülent Ecevit Üniversitesi Tıp Fakültesi, Bioistatistik Anabilim Dalı, Zonguldak
\end{abstract}

AMAÇ: Akut mezenterik iskemi (AMI) olgularının \%50-70'i ölümcül olup, hızlı ve etkili bir klinik değerlendirme ve tedavi gerektiren bir vasküler acil olarak kabul edilmektedir. Mevcut geriye dönük çalışmada, biz AMI erken tanısında nötrofil/lenfosit oranının (NLR) olası yararını ve bu oranın AMI ile non-vasküler bağırsak nekrozu (NVBN) ayıııı tanısında etkili olup olmadığını araştırdık.

GEREÇ VE YÖNTEM: Bu çalışmada I Mayıs 20I0-30 Nisan 2015 tarihleri arasında 58 AMI, 62 NVBN ve 62 kontrol hastası incelendi. Akut mezenterik iskemi tanısıyla laparotomi ve/veya bağırsak rezeksiyonu yapılan hastalar çalışma grubuna alındı. İnkarsere ve strangüle herni nedeniyle segmenter bağırsak rezeksiyonu yapılan hastalar NVBN grubuna alındı. Kontrol grubu hastaları non-spesifik karın ağrısı nedeniyle acil servise başvuran hastalarda oluşturuldu.

BULGULAR: Mortalite oranı AMI grubunda \%5I.7, NVBN grubunda \%4.8 idi. Akut mezenterik iskemi grubunda lökosit (WBC) sayısı, C-reaktif protein (CRP) ve eritrosit dağılım aralığı diğer gruplardan daha yüksekti. Nötrofil/lenfosit oranı, AMI ve NVBN grubunda kontrol grubundan daha yüksekti $(p<0.00 I)$, ancak AMI ve NVBN grupları arasında fark yoktu. Ayrıca, NVBN grubunda WBC sayısı ve CRP control grubundan daha yüksekti $(p<0.00$ I).

TARTIŞMA: Ameliyat öncesi NLR düzeyinin AMI tanısında yardımcı olacağını ve AMI ile bağırsak nekrozu ile seyreden NVBN gibi durumlarla ayrıcı tanıda kullanabileceğini düşünmekteyiz. Bundan dolayı, bu tür hastalarda NLR klinik muayeneye ek olarak hesaplanmalıdır.

Anahtar sözcükler: Akut mezenterik iskemi; NLR; serum belirteçleri; tanı.

Ulus Travma Acil Cerrahi Derg 2016;22(4):344-349 doi: 10.5505/tjtes.2015.28235 